\title{
ANTISTRESS EFFECTS OF N-STEAROYLETHANOLAMINE IN RATS WITH CHRONIC SOCIAL STRESS
}

\author{
T. M. HORID'KO', H. V. KOSIAKOVA' ${ }^{1}$, A. G. BERDYSHEV ${ }^{1}$, O. F. MEGED ${ }^{1}$, \\ E. A. GUDZ ${ }^{1}$, O. V. ONOPCHENKO' ${ }^{1}$, V. S. ASMOLKOVA' ${ }^{1}$, V. M. LOZOVA', \\ E. V. TUKALENKO', O. V. BONDARENKO', I. I. TUBALZEVA', \\ O. A. KOVALENKO', M. Y. MAKARCHUK ${ }^{2}$, N. M. HULA ${ }^{1}$ \\ ${ }^{1}$ Palladin Institute of Biochemistry, National Academy of Sciences of Ukraine, Kyiv; \\ ${ }^{2}$ ESC Institute of Biology and Medicine, \\ Taras Shevchenko National University of Kyiv, Ukraine; \\ e-mail:TanGoRi@ukr.net
}

The aim of this study was to evaluate the effects of N-stearoylethanolamine (NSE) on the number of biochemical parameters that are involved in the development of the stress response (corticosterone, catecholamines, testosterone, TBARS, nitric oxide, serotonin), memory state, exploratory activity and antinociceptive response in rats, using a model of chronic social stress. It has been demonstrated that administration of NSE (14 days, intragastrically, $50 \mathrm{mg} / \mathrm{kg}$ ) after chronic social stress developed (stress was induced by daily agonistic interaction between animals), normalizes plasma content of corticosterone, testosterone, epinephrine, norepinephrine, dopamine, TBARS, nitrite-anion and increases serotonin level that leads to memory state improvement and increase in exploratory activity in rats. The tail-flick latency did not change, that is it remained at the level of stressed animals.

Key words: $N$-stearoylethanolamine, chronic social stress, corticosterone, catecholamines, testosterone, TBARS, nitric oxide, serotonin.

$\mathrm{T}$ he impact of stress on human health is widely recognized, primarily, long term and intensive stress factors cause a depletion of body's compensatory mechanisms, where stress response from adaptation link changes to stress-illness link, contributing to the pathogenesis of many diseases (mental, endocrine, cardiovascular, gastrointestinal, etc.) $[1,2]$.

In recent years, social stress factors have gained considerable effect on life of a contemporary human that triggers different disturbances in the functioning of internal organs, followed by the complex of mental disorders and behavioral changes [3, 4].

Therefore, one of the most important tasks of modern biology and medicine is the prevention of the damaging effects of stress by finding new effective, natural, non-addictive and safe compounds with strong anti-stress activity, which do not cause allergic reactions, do not have any side-effects or age restrictions and are compatible with other medications.
In this field the promising pharmacological tools may be the family of bioactive compounds $\mathrm{N}$-acylethanolamines (NAE). NAEs are naturally occurring membrane components with a wide range of biological and pharmacological actions that do not exert toxic effects. In view of the diverse biological actions of $\mathrm{N}$-acylethanolamines, it is reasonable to study the effect of $\mathrm{N}$-stearoylethanolamine on memory state, exploratory activity and antinociceptive response, in addition to a number of biochemical parameters in rats with chronic social stress.

\section{Materials and Methods}

N-stearoylethanolamine with the 99.8 percent of purity was synthesized in the Department of Lipid Biochemistry of the Palladin Institute of Biochemistry [5].

The study was carried out on 74 mature outbred white male rats (controls -14 rats, domestics - 30 rats, intruders - 30 rats). For one week before the

(C) 2017 Horid'ko T. M. et al. This is an open-access article distributed under the terms of the Creative Commons Attribution License, which permits unrestricted use, distribution, and reproduction in any medium, provided the original author and source are credited. 
start of the experiment animals were housed in plastic cages with iron lattice top either individually to remove the previously obtained social experience (control and intruders, body weight $185 \pm 17 \mathrm{~g}$,) or with a harem of females to increase aggressiveness (domestics, body weight 350-400 g). Domestics were used only to induce chronic social stress in experimental animals (intruders). Only rats from control group and intruders were involved in biochemical and physiological investigations. Animals were given ad libitum access to food (granulated diet, Vitameks, Ukraine) and water. All animal procedures were conducted in accordance with the requirements of European Convention for the Protection of Vertebrate Animals Used for Experimental and Other Scientific Purposes (Strasbourg, 1986).

Experimental animals were divided into 3 groups: controls -14 rats, chronic social stress induction - 15 rats (intruders); N-stearoylethanolaminetreated after induced chronic social stress - 15 rats (intruders).

Stress was induced by daily agonistic interaction between animals (intruder and domestic) [6]. Daily during 14 days unfamiliar male (intruder), which was smaller in weight, was put into the home cage of the domestic for $30 \mathrm{~min}$. For 10 min they were held together in agonistic interaction. During the next 20 min they were separated by transparent membrane with tiny holes for visual and olfactory contact. After the last stress-inducing interaction $\mathrm{N}$-srearoylethanolamine was administrated intragastrically to 1 group of animals daily during 14 days at a dose of $50 \mathrm{mg} / \mathrm{kg}$ of body weight. Other groups of animals without NSE treatment received equal volume of distilled water by the same administration method.

Rats of all groups were tested in the Novel Object Recognition (NOR) behavioral test [7]. The results of NOR test are presented as Discrimination Index (DI) measured by the difference in the exploration time of "novel" and "familiar" objects divided by the total time of explorations. In addition, the level of rats' exploratory activity was estimated as the total time spent for exploring both objects.

Antinociceptive response was determined using tail-flick assay [8]. Animals were placed in a clear plastic box, where application of thermal radiation (by focused light) on a blackened spot 1-2 cm from the tip of the tail of the animal provoked withdrawal of the tail by a brief vigorous movement. The withdrawal time was recorded as tail flick latency by using an analgesiometer (Panlab, LE 7106 Light Beam Analgesy-Meter, at an infrared intensity of 50).

At the end of the experiments, the rats (controls and intruders) were decapitated under $\mathrm{CO}_{2}$ anesthesia and blood was rapidly collected for biochemical assays.

The level of plasma corticosterone, epinephrine, norepinephrine, dopamine and serotonin was measured by ELISA (IBL, Germany), testosterone ELISA (LDN, Germany) using BioRad 680 microplate reader (BioRad Laboratories Inc., Hercules, California, USA).

The intensity of lipid peroxidation was analyzed by estimating the amount of TBA reactive substances [9]. Measurement of nitrite-anions was made by Green method [10].

The data, presented as mean values \pm standard errors of the means (SEM), were compared using Student's unpaired $t$-test. The differences were considered significant at $P<0.05$.

\section{Results and Discussion}

The results of the experiments, presented in a Figure, indicated that chronic social stress causes a significant increase in plasma level of corticosterone $(A)$, epinephrine $(C)$, norepinephrine $(D)$, dopamine $(E)$, serotonin $(F)$, TBA reactive substances $(G)$ and reduction in testosterone $(B)$ and nitrite-anion $(H)$ content. In addition, stress development resulted in the decreased value of DI $(J)$ and enhanced latency time in tail flick test $(I)$. In contrast, the level of exploratory activity did not change $(K)$.

The NSE administration normalized plasma content of corticosterone $(A)$, testosterone $(B)$, epinephrine $(C)$, norepinephrine $(D)$, dopamine $(E)$, TBA reactive substances $(G)$, nitrite-anion $(H)$ and triggered remarkable increase in serotonin level $(F)$ compared to stressed animals. This effect of NSE was accompanied by normalization of DI value $(J)$ and considerable increase in exploratory activity level $(K)$. The tail-flick latency did not change, it remained at the level of stressed animals $(I)$.

One of the main mechanisms of adaptation to stress is activation of the hypothalamic-pituitary-adrenal system and increased secretion of stress hormones, primarily, glucocorticoids.

Glucocorticoids directly or indirectly regulate main physiological and biochemical processes in the body. Namely, the increased level of glucocorticoids has protective effects against the development 

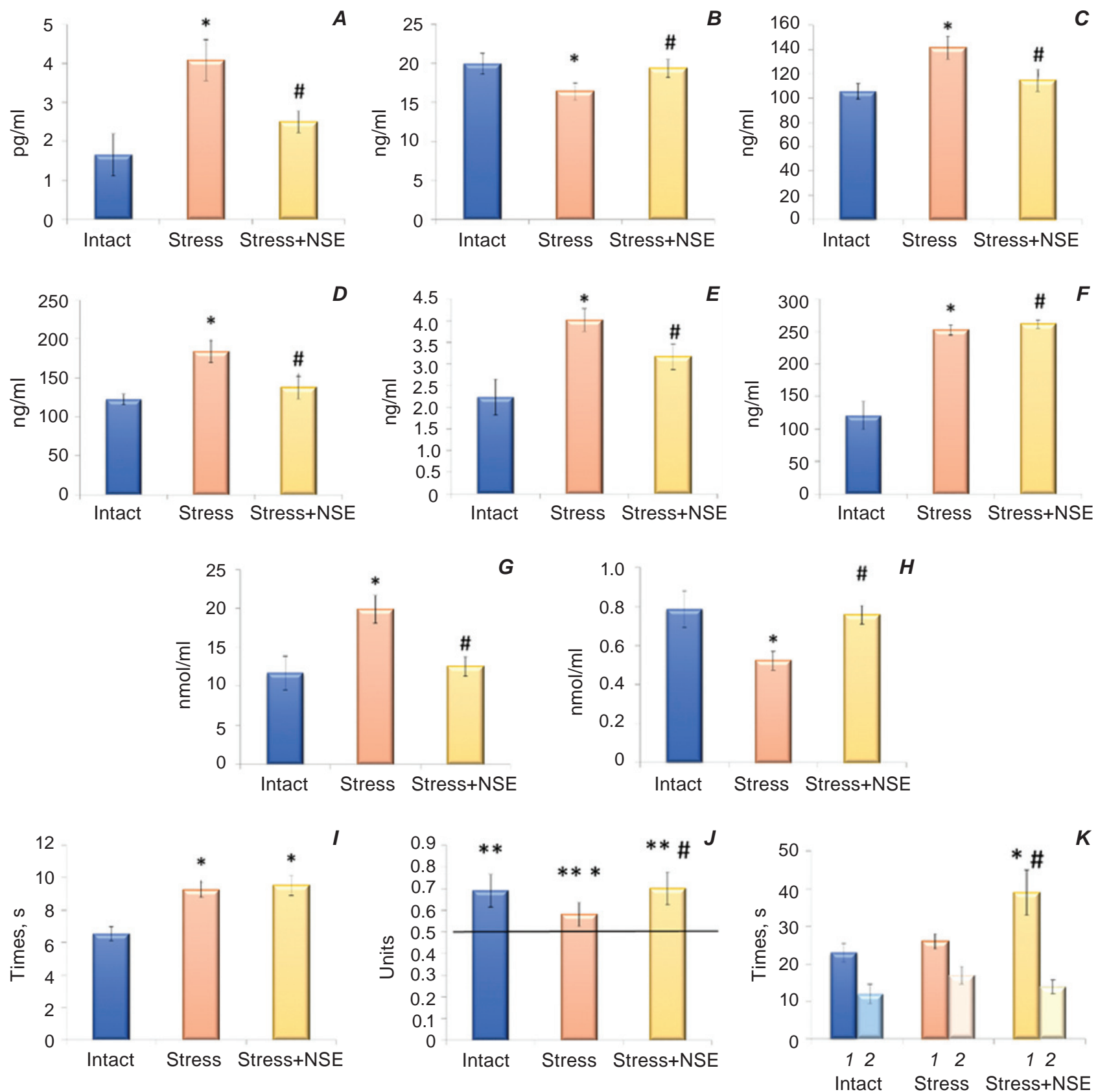

Plasma level of corticosterone (A), testosterone $(B)$, epinephrine $(C)$, norepinephrine $(D)$, dopamine (E), serotonin $(F)$, TBA reactive substances $(G)$ and nitrite-anion $(H)$, in addition to tail-flick latency $(I)$, DI value in selection phase $(J)$ and duration of objects exploration in test of object recognition $(K)$ in rats with induced chronic social stress and under NSE treatment. Values represent the mean $\pm S E M ; * P<0.05$ versus Intact rats; $\# P<0.05$ versus Stress rats; ** $P<0.01$ versus $D I=0.5$

of post-traumatic symptoms triggered by traumatic stress [11].

On the other hand, the enhanced level of glucocorticoids induced by prolonged stress leads to negative consequences - indigestion, irritability, obesity, diabetes, hypertension, insomnia, immunosuppression, poor memory, etc.
It is also noteworthy that significantly prolonged glucocorticoid elevations caused hippocampal atrophy (the brain structure which is responsible for memory formation and learning, mood, regulation of neuroendocrine stress hormones, which is extremely sensitive to stress, injury, oxygen and 
glucose deprivation) and deficits in hippocampusdependent memory tasks [12-14].

As in the case for the hippocampus, glucocorticoids also affect morpho-functional characteristic of other brain regions, namely, the prefrontal cortex, which is important for working memory, executive function, and self-regulatory behaviors, controls anxiety, emotions and is suggested to control aggressive behavior) [12]. Thus, recent findings indicate correlation between enhanced level of glucocorticoids and synapse loss in the prefrontal cortex, in addition to impairedworking memory [15].

In recent years, a large number of studies confirmed the leading role of elevated glucocorticoids' level in inflammation development in certain brain regions (namely, hippocampal damage) and in the entire central nervous system [16, 17].

Depression and post-traumatic stress disorder is often associated with the hypersecretion of glucocorticoids and impaired hippocampal function $[13,14]$.

Elevated glucocorticoid levels are observed in many neurodegenerative disorders including Alzheimer's and Parkinson's diseases [18]. Recent studies confirmed cause-effect relationships between prolonged stress, elevated levels of glucocorticoids, memory impairment, brain aging and neurodegenerative disorders [2].

In the model of chronic social stress or social deprivation across individuals of different primate societies with subordinate status exhibited higher relative levels of circulating glucocorticoids [19]. These findings suggest that aging in this animals' subtype correlates with behavioral disturbances that are similar to dementia in humans.

Thus, elevated levels of corticosteroids, which occur during chronic stress, lead to impaired brain morphology and neuroplasticity, with following changes in behavior, memory state and learning.

This finding is consistent with our data on the corticosterone level (Fig., $A$ ) and confirms that social stress induced daily for two weeks in rats causes memory impairment (significant reduction of DI (Fig., $J$ )).

Daily administration of NSE for two weeks after chronic social stress improved memory state and attention ((Fig., $J$ ), an increase in DI value), and caused an increase in the level of exploratory activity in rats (Fig., $K$ ). Thus, the normalization of corticosterone level under the NSE administration may be one of the causative factors for the improvement of memory and exploratory activity in rats.
It is well known that $\mathrm{N}$-acylethanolamines (mainly N-palmitoylethanolamine, anandamide, $\mathrm{N}$-oleoylethanolamine) exert membrane protective, antioxidant, immunomodulatory, anti-inflammatory, anti-toxic and other activities. Furthermore, NAEs regulate blood-brain barrier permeability [20] and exhibit regulatory effects on the adrenal cortex function in rats [21]. Some representatives of the $\mathrm{N}$-acylethanolamines family, mainly with unsaturated fatty acids, bind to cannabinoid receptors and are included in the endocannabinoid system. Saturated NAEs (such as N-palmitoylethanolamine and $\mathrm{N}$-stearoylethanolamine) also exert cannabimimetic activity, however, in contrast with unsaturated members, they do not interact with cannabinoid receptors and exhibit their effect through activation of other receptors (e.g., vanilloid, PPARs) or via receptorindependent mechanism [22]. In addition, saturated NAEs inhibit the degradation of unsaturated NAEs that leads to an enhancement of their tissue levels, thus, increasing their biological action [23].

Endocannabinoid system (a well-studied endogenous ligand is anandamide and other members of the NAEs family), which is activated immediately by the stress offset and elevated level of circulating glucocorticoids, plays an important role in the formation and regulation of stress response, modulation of cognitive and emotional processing. The impairment of endocannabinoid signaling that is triggered by chronic stress leads to an increase in stress-related and anxiety-like behavior, development of mental and emotional disorders that are accompanied by the impairment of memory and learning ability.

Meanwhile in rodents exposed to chronic social stress the inhibition of FAAH (fatty acid amide hydrolase)-induced degradation of $\mathrm{N}$-arachidonoylethanolamide reduces the hypothalamic-pituitary-adrenal axis, followed by the decrease in basal hypersecretion of glucocorticoids and prevention of anxiety disorders [24].

Furthermore, it was demonstrated that FAAH inhibitors ameliorate memory state and learning ability [25]. The FAAH inhibitors can produce their effects through PPAR $\alpha$ and through cannabinoid CB1-receptors [26].

It is known that stress increases the permeability of the blood-brain barrier (BBB), resulting in dysfunction of the central nervous system. The inhibition of endocannabinoids' hydrolysis can help to preserve the integrity of BBB and, thus, prevents the development of neurological and behavioral disorders in rats [20]. 
The results of our study showed that NSE may compensate changes in the level of circulating glucocorticoids (corticosterone) and cognitive alterations in rats with chronic social stress. This effect of NSE may be mainly associated with its adaptogenic, neuroprotective and anti-inflammatory properties, in addition to inhibition of FAAH-mediated degradation of anandamide and modulation of BBB permeability.

Enhanced glucocorticoids secretion that is mediated by chronic stress also contributes to suppression of the reproductive system [27]. Findings in women indicate that chronically high cortisol levels may disrupt the menstrual cycles and reduce fertility [27]. Meanwhile in man chronically elevated levels of cortisol inhibit testosterone release, resulting in erectile dysfunction and loss of libido. Low testosterone levels correlate with memory impairment, reduction of concentration abilities and co-occurrence of irritability, anxiety and depression [28]. In agreement with this, the reduced level of testosterone has been found in plasma of subjects with subordinate status [29].

In our study we also found the reduction of plasma testosterone level and exploratory activity in rats with chronic social stress (Fig., $B, J$ ).

Daily administration of NSE for two weeks to stressed rats led to normalization of testosterone level, improved memory state and attention (Fig., $J$ ), and increased the level of exploratory activity that is consistent with longer time exploring new object (Fig., $K$ ).

According to the published data, the decline in testosterone level is associated with structural and functional changes in the testis as a result of an oxidative and other types of stress development, as well as a result of an enhanced level of estrogen in males under different pathological conditions such as metabolic syndrome, diabetes, obesity etc. [30].

In our previous studies, it has been shown that $\mathrm{N}$-stearoylethanolamine prevents pathological changes in tissues via different biochemical mechanisms.

The key role in the formation of stress response is played by hypothalamo-pituitary-adrenocortical and sympatho-adrenal axises. Firstly, in response to stress exposure there is an increase in the level of blood catecholamine, which causes physiological responses such as heart palpitations, increased blood pressure, inhibition of digestive functions and excitement. In addition, it mediates the release of epinephrine by adrenal cortex and glucocorticoids.
State of the sympathetic division of the autonomic nervous system remains tense throughout the period of the stressor action and this may be one of the causes of psychosomatic diseases and post-traumatic stress disorder.

Moreover, the level of circulating catecholamines plays an important role in the formation of "fight-or-flight" response and modulation of morpho-functional characteristics of brain regions that are involved in memory formation. Thus, earlier it has been shown that epinephrine, released into blood from the adrenal medulla in response to stress, is a potent and dose-dependent enhancer of learning and memory processing [31]. Low doses of epinephrine have little effect on memory, moderate doses enhance memory, and high levels impair memory. One of the possibilities, regarding the mechanisms by which epinephrine can influence brain functions, is through the activation of $\beta$-adrenergic receptors on afferent neuronal axons of vagus nerve that mediates glucose release [31]. Additionally, the role of norepinephrine was confirmed in mediating the actions of other stress hormones on the preservation of memory (including epinephrine and glucocorticoids) [32]. Other studies demonstrated the powerful influence of dopamine on cognitive functions. In addition, dopamine regulates the processes of adaptation, emotional perception and motivation [33].

As noted above (see. Fig.), in plasma of rats with chronic social stress we detected increased levels of catecholamines - epinephrine, norepinephrine and dopamine that indicates the activation of sympatho-adrenal system and significant memory impairments.

Daily administration of NSE to rats after two weeks of stress induction normalized the plasma level of the above catecholamines, improved memory state and increased the exploratory activity in rats (Fig., $C, D, E, J, K$ ).

Furthermore, NAEs with saturated and unsaturated lipid chains can modulate steroidogenesis in the adrenal cortex [21, 34]. Nowadays, there is no published information on the possible mechanisms of NAEs' influence on synthesis of catecholamines.

It is known that nitric oxide inhibits the release of catecholamines from the adrenal glands and nerve terminals. Inhibition of NO synthesis leads to activation of sympatho-adrenal axis, followed by the modulation of catecholamines content. Previously, it has been shown that NSE regulates the level of nitric oxide by modulating the activity of constitutive and 
inducible NO synthase in various pathological conditions [35]. Thus, we can suggest that normalization effect of N-stearoylethanolamine on the plasma level of catecholamines in rats with chronic social stress (Fig., $C, D, E$ ) can be mediated by its modulatory activity on the nitrogen oxide content (Fig., $H$ ).

Biogenic amines such as serotonin and catecholamines are involved in the modulation of pain [36]. Peripheral dopamine modulates peripheral pain response [37], the reduction of serotonin level is associated with major depressive disorder and increased antinociceptive response [38]. In addition, alterations in function of central serotonin and noradrenergic systems cause pain syndrome and emotional discomfort [36].

In our study, chronic social stress in rats led to a significant increase in plasma content of epinephrine, norepinephrine, dopamine and serotonin (Fig., $C, D, E, F$ ) that was associated with an increase in thermal pain threshold (Fig., I). The NSE administration to rats with induced chronic stress triggered normalization of catecholamines level and significant increase in serotonin content, thus, did not affect the level of the pain threshold in rats.

It is well known that lipid peroxidation plays a crucial role in the adaptation, however, the exposure to intense and chronic stressors, which correlates with increased release of stress hormones (glucocorticoids and catecholamines), transforms lipid peroxidation from adaptive response to damaging effects.

Recent data, obtained using models of social stress in rats and chronic stress in mice, demonstrated the correlation between the intensity of oxidative stress, inflammation and anxiety-depression-like behaviors, as well as memory impairment [39]. In addition, enhanced levels of glucocorticoids and catecholamines in response to long-term stress directly or indirectly intensified oxidative and nitrosative stress [40, 41].

According to the results of our study, chronic social stress in rats led to a significant increase in plasma content of corticosterone and catecholamines (Fig., $A, C, D, E$ ), enhanced formation of TBA reactive substances (Fig., $J$ ) - markers of the lipid peroxidation intensity and memory alterations (Fig., $J$ ).
The treatment with NSE after stress induction for two weeks normalized the level of TBA reactive substances, corticosterone and catecholamines, and moreover, ameliorated the memory state and exploratory activity in rats (Fig., $A, C, D, E, G, J, K$ ).

This effect of NSE on TBA reactive substances content may be mediated by its antioxidant, membranotropic and anti-inflammatory activity, in addition to its compensatory action on the level of circulating glucocorticoids and catecholamines.

Interestingly, nitric oxide also plays an important regulatory role in the stress response and adaptation to stress action [42], and is also involved in pain modulation and mechanisms involved in longterm memory [36].

The results of our study, which are shown in Fig., $H$ suggest that chronic social stress causes a decrease in the content of one of the stable metabolites of nitric oxide - nitrite anion to almost $44 \%$ in rat plasma. Daily use of N-stearoylethanolamine after two weeks of stress induction causes normalization of plasma nitrite anion content in rats.

These findings support the earlier reported data about the plasma level of catecholamines in stressed rats and under the NSE treatment (Fig., $C, D, E$ ).

Therefore, two-week administration of $\mathrm{N}$-stearoylethanolamine after induction of chronic social stress in rats normalizes plasma content of corticosterone, testosterone, epinephrine, norepinephrine, dopamine, TBARS, nitrite-anion and increases serotonin level that contributes to the improvement of memory state, an increase in the level of exploratory activity and preserve the value of antinociceptive response in rats that confirms an antistress and adaptogenic action of NSE.

Finally, these findings can form the basis for a drug development to treat chronic stress in humans caused by the influence of socio-political, economic, and other traumatic factors.

Publications are based on the research provided by the grant support of the State Fund for Fundamental Research (F64/28-2016). 


\section{АНТИСТРЕСОВІ ЕФЕКТИ N-СТЕАРОЇЛЕТАНОЛАМІНУ ЗА ХРОНІЧНОГО СОЦІАЛЬНОГО СТРЕСУ В ЩУРIВ}

\author{
Т. М. Горідько ${ }^{1}$, Г. В. Косякова ${ }^{1}$, \\ А. Г. Бердишев ${ }^{1}$ О. Ф. Мегедь ${ }^{1}$, С. А. Гудзь ${ }^{1}$, \\ О. В. Онопченко ${ }^{1}$ В. С. Асмолкова ${ }^{1}$, \\ В. М. Лозова ${ }^{2}$, С. В. Тукаленко \\ О. В. Бондаренко ${ }^{2}$, I. І. Тубальиева ${ }^{2}$, \\ О. А. Коваленко ${ }^{2}$ М. Ю. Макарчук ${ }^{2}$, \\ Н. М. Гула ${ }^{1}$
}

\author{
${ }^{1}$ Інститут біохімії ім. О. В. Палладіна \\ НАН України, Київ; \\ ${ }^{2}$ ННЦ «Інститут біології та медицини», \\ Київський національний університет \\ імені Тараса Шевченка, Україна; \\ e-mail: TanGoRi@ukr.net
}

На моделі хронічного соціального стресу в щурів досліджено вплив N-стеароїлетаноламіну на низку біохімічних показників, що задіяні у формуванні стрес-реакції організму (кортикостерон, катехоламіни, ТБК-активні продукти, нітрит-аніон, серотонін, тестостерон). Також досліджено стан пам'яті, рівень дослідницької активності та больової чутливості у тварин. Показано, що за застосування N-стеароїлетаноламіну (14 днів, інтрагастрально, 50 мг/кг) після розвитку в щурів хронічного соціального стресу (який спричинювали щоденними протягом 14 днів агоністичними взаємодіями між тваринами) відбувалася нормалізація вмісту кортикостерону, тестостерону, адреналіну, норадреналіну, допаміну, ТБК-активних продуктів, нітританіону та вірогідне зростання вмісту серотоніну. Ці зміни сприяли покращенню стану пам'яті та зростанню рівня дослідницької активності в щурів. При цьому, за дії N-стеароїлетаноламіну рівень больової чутливості в тварин не змінювався, а залишався на рівні значень у стресованих тварин.

К л ю ч о в і с л о в а: N-стеароїлетаноламін, хронічний соціальний стрес, кортикостерон, катехоламіни, тестостерон, ТБК-активні продукти, оксид азоту, серотонін.

\section{АНТИСТРЕССОВЫЕ ЭФФЕКТЫ N-СТЕАРОИЛЭТАНОЛАМИНА ПРИ ХРОНИЧЕСКОМ СОЦИАЛЬНОМ СТ РЕССЕ У КРЫС}

\author{
T. Н. Горидько \\ А. Г. Бердышев ${ }^{1}$, Е. Ф. Мегедь ${ }^{1}$, Е. А. Гудзъ ${ }^{1}$, \\ А. В. Онопченко ${ }^{1}$ В. С. Асмолкова ${ }^{1}$, \\ В. Н. Лозова ${ }^{1}$, Е. В. Тукаленко ${ }^{2}$, \\ А. В. Бондаренко ${ }^{2}$, И. И. Тубальиева ${ }^{2}$, \\ А. А. Коваленко ${ }^{2}$, Н. Е. Макарчук ${ }^{2}$, \\ Н. М. Гулая ${ }^{1}$
}
${ }^{1}$ Институт биохимии им. А. В. Палладина НАН Украины, Киев;
2УНЦ «Институт биологии и медицины», Киевский национальный университет имени Тараса Шевченко, Украина; e-mail: TanGoRi@ukr.net

На модели хронического социального стресса у крыс исследовано влияние $\mathrm{N}$-стеароилэтаноламина на ряд биохимических показателей, которые задействованы в развитии стресс-реакции организма (кортикостерон, катехоламины, ТБК-активные продукты, нитрит-анион, серотонин, тетстостерон). Также исследовали состояние памяти, уровень исследовательской активности и болевой чувствительности у животных. Показано, что применение N-стеароилэтаноламина (14 дней, интрагастрально, 50 мг/кг) после развития у крыс хронического социального стресса (стресс вызывали каждодневными на протяжении 14 дней агонистическими взаимодействиями между животными) приводило к нормализации содержания кортикостерона, тестостерона, адреналина, норадреналина, допамина, ТБК-активных продуктов, нитрит-аниона и к достоверному увеличению содержания серотонина. Эти изменения способствовали улучшению состояния памяти и повышению уровня исследовательской активности у крыс. При этом уровень болевой чувствительности у животных, которым вводили $\mathrm{N}$-стеароилэтаноламин, не изменялся, а оставался на уровне значений у стрессированных животных.

К л юче вы е с ло в а: $\mathrm{N}$-стеароилэтаноламин, хронический социальный стресс, кортикостерон, катехоламины, тестостерон, ТБКактивные продукты, оксид азота, серотонин. 


\section{References}

1. Dong T, Cheng YW, Yang F, Sun PW, Zhu CJ, Zhu L, Zhang GX. Chronic Stress Facilitates the Development of Deep Venous Thrombosis. Oxid Med Cell Longev. 2015; 2015: 384535.

2. Vyas S, Rodrigues AJ, Silva JM, Tronche F, Almeida OF, Sousa N, Sotiropoulos I. Chronic Stress and Glucocorticoids: From Neuronal Plasticity to Neurodegeneration. Neural Plast. 2016; 2016: 6391686.

3. Ogawa S., Lee Y.A., Yamaguchi Y., Shibata Y., Goto Y. Associations of acute and chronic stress hormones with cognitive functions in autism spectrum disorder. Neuroscience. 2017; 343: 229-239.

4. Ceccato S, Kudielka BM, Schwieren C. Increased Risk Taking in Relation to Chronic Stress in Adults. Front Psychol. 2016; 6: 2036.

5. Pat. 81861 UA, ICP (2007.01) C07C 215/00, C07C 229/02. Methodofobtaining $N$-acylethanolamines / Hula N. M., Marhitych V. M., Horid'ko T. M., Artamonov M. V., Zhukov O. D., Klimashevs'kyi V. M. Publ. 11.02.2008, Bul. N 3. (In Ukrainian).

6. Kudryavtseva NN. A sensory contact model for the study of aggressive and submissive behavior in male mice. Aggress Behav. 1991; 17(5): 285291.

7. Antunes M, Biala G. The novel object recognition memory: neurobiology, test procedure, and its modifications. Cogn Process. 2012; 13(2): 93110.

8. D'amour FE, Smith DL. A method for determining loss of pain sensation. J Pharmacol Exp Ther. 1941; 72(1): 74-79.

9. Mel'nychuk SD, Kuz'menko AI, Margitich VM, Govseeva NN, Gorid'ko TN, Hulaia NM. Effect of carbon dioxide on free radical processes as affected by artificial hypobiosis in rats. $U k r$ Biokhim Zhurn. 1998; 70(1): 87-94. (In Russian).

10. Green LC, Wagner DA, Glogowski J, Skipper PL, Wishnok JS, Tannenbaum SR. Analysis of nitrate, nitrite, and $\left[{ }^{15} \mathrm{~N}\right]$ nitrate in biological fluids. Anal Biochem. 1982; 126(1): 131-138.

11. Rao RP, Anilkumar S, McEwen BS, Chattarji S. Glucocorticoids protect against the delayed behavioral and cellular effects of acute stress on the amygdala. Biol Psychiatry. 2012; 72(6): 466475.
12. McEwen BS, Nasca C, Gray JD. Stress Effects on Neuronal Structure: Hippocampus, Amygdala, and Prefrontal Cortex. Neuropsychopharmacology. 2016; 41(1): 3-23.

13. Wingenfeld K, Wolf OT. Stress, memory, and the hippocampus. Front Neurol Neurosci. 2014; 34: 109-120.

14. Wingenfeld K, Wolf OT. Effects of cortisol on cognition in major depressive disorder, posttraumatic stress disorder and borderline personality disorder - 2014 Curt Richter Award Winner. Psychoneuroendocrinology. 2015; 51: 282-295.

15. Anderson RM, Birnie AK, Koblesky NK, Romig-Martin SA, Radley JJ. Adrenocortical status predicts the degree of age-related deficits in prefrontal structural plasticity and working memory. J Neurosci. 2014; 34(25): 8387-8397.

16. Sorrells SF, Munhoz CD, Manley NC, Yen S, Sapolsky RM. Glucocorticoids increase excitotoxic injury and inflammation in the hippocampus of adult male rats. Neuroendocrinology. 2014; 100(2-3): 129-140.

17. Sorrells SF, Caso JR, Munhoz CD, Hu CK, Tran KV, Miguel ZD, Chien BY, Sapolsky RM. Glucocorticoid signaling in myeloid cells worsens acute CNS injury and inflammation. J Neurosci. 2013; 33(18): 7877-7889.

18. Herrero MT, Estrada C, Maatouk L, Vyas S. Inflammation in Parkinson's disease: role of glucocorticoids. Front Neuroanat. 2015; 9: 32.

19. Abbott DH, Keverne EB, Bercovitch FB, Shively CA, Mendoza SP, Saltzman W, Snowdon CT, Ziegler TE, Banjevic M, Garland T Jr, Sapolsky RM. Are subordinates always stressed? A comparative analysis of rank differences in cortisol levels among primates. Horm Behav. 2003; 43(1): 67-82.

20. Hind WH, Tufarelli C, Neophytou M, Anderson SI, England TJ, O'Sullivan SE. Endocannabinoids modulate human blood-brain barrier permeability in vitro. Br J Pharmacol. 2015; 172(12): 3015-3027.

21. Zhukov OD, Artamonov MV, Klimashevsky VM, Govseeva NM, Margitich VM, Gulaya NM. N-acylethanolamines - the new class of naturally occurring adrenal modulators. Ukr Biokhim Zhurn. 2000; 72(2): 24-27. (In Ukrainian). 
22. Maccarrone M, Cartoni A, Parolaro D, Margonelli A, Massi P, Bari M, Battista N, Finazzi-Agrò A. Cannabimimetic activity, binding, and degradation of stearoylethanolamide within the mouse central nervous system. Mol Cell Neurosci. 2002; 21(1): 126-140.

23. Costa B, Comelli F, Bettoni I, Colleoni M, Giagnoni G. The endogenous fatty acid amide, palmitoylethanolamide, has anti-allodynic and anti-hyperalgesic effects in a murine model of neuropathic pain: involvement of CB(1), TRPV1 and PPARgamma receptors and neurotrophic factors. Pain. 2008; 139(3): 541-550.

24. Gunduz-Cinar O, Hill MN, McEwen BS, Holmes A. Amygdala FAAH and anandamide: mediating protection and recovery from stress. Trends Pharmacol Sci. 2013; 34(11): 637-644.

25. Hlavacova N, Chmelova M, Danevova V, Csanova A, Jezova D. Inhibition of fatty-acid amide hydrolyse (FAAH) exerts cognitive improvements in male but not female rats. Endocr Regul. 2015; 49(3): 131-136.

26. Panlilio LV, Justinova Z, Goldberg SR. Inhibition of FAAH and activation of PPAR: new approaches to the treatment of cognitive dysfunction and drug addiction. Pharmacol Ther. 2013; 138(1): 84-102.

27. Whirledge S, Cidlowski JA. A role for glucocorticoids in stress-impaired reproduction: beyond the hypothalamus and pituitary. Endocrinology. 2013; 154(12): 4450-4468.

28. Hamson DK, Roes MM, Galea LA. Sex Hormones and Cognition: Neuroendocrine Influences on Memory and Learning. Compr Physiol. 2016; 6(3): 1295-1337.

29. Eisenegger C, Haushofer J, Fehr E. The role of testosterone in social interaction. Trends Cogn Sci. 2011; 15(6): 263-271.

30. Fernández-Miró M, Chillarón JJ, Pedro-Botet J. Testosterone deficiency, metabolic syndrome and diabetes mellitus. Med Clin (Barc). 2016; 146(2): 69-73.

31. Gold PE. Regulation of memory - from the adrenal medulla to liver to astrocytes to neurons. Brain Res Bull. 2014; 105: 25-35.
32. Ferry B, McGaugh JL. Role of amygdala norepinephrine in mediating stress hormone regulation of memory storage. Acta Pharmacol Sin. 2000; 21(6): 481-493.

33. Ranganath A, Jacob SN. Doping the Mind: Dopaminergic Modulation of Prefrontal Cortical Cognition. Neuroscientist. 2016; 22(6): 593-603.

34. Mikosha A, Kovzun O, Zhukov A, Gulaya N. Effect of dopamine and long-chain $\mathrm{N}$-acylethanolamines on steroidogenesis in rat adrenal gland in vitro. Med Sci Res. 1998; 26: 85-88.

35. Gulaya NM, Kosiakova GV, Berdyshev AG. The effects of N-stearoylethanolamine on the NOsynthase way of NO generation in the aorta and heart of streptozotocin-induced diabetic rats. Ukr Biokhim Zhurn. 2007; 79(5): 153-158. (In Ukrainian).

36. Millan MJ. Descending control of pain. Prog Neurobiol. 2002; 66(6): 355-474.

37. Dawson A, Stensson N, Ghafouri B, Gerdle B, List T, Svensson P, Ernberg M. Dopamine in plasma - a biomarker for myofascial TMD pain? J Headache Pain. 2016; 17(1): 65.

38. Paul-Savoie E, Potvin S, Daigle K, Normand E, Corbin JF, Gagnon R, Marchand S. A deficit in peripheral serotonin levels in major depressive disorder but not in chronic widespread pain. Clin J Pain. 2011; 27(6): 529-534.

39. Patki G, Solanki N, Atrooz F, Allam F, Salim S. Depression, anxiety-like behavior and memory impairment are associated with increased oxidative stress and inflammation in a rat model of social stress. Brain Res. 2013; 1539: 73-86.

40. Seo JS, Park JY, Choi J, Kim TK, Shin JH, Lee JK, Han PL. NADPH oxidase mediates depressive behavior induced by chronic stress in mice. J Neurosci. 2012; 32(28): 9690-9699.

41. Meiser J, Weindl D, Hiller K. Complexity of dopamine metabolism. Cell Commun Signal. 2013; 11(1): 34.

42. Gulati K, Joshi JC, Ray A. Recent advances in stress research: Focus on nitric oxide. Eur $J$ Pharmacol. 2015; 765: 406-414. 